\title{
Protective Effect of Meso-Tetrakis-(3,5-di-tert-butyl- 4-hydroxyphenyl)porphyrin on the In Vivo Impact of Trimethyltin Chloride on the Antioxidative Defense System
}

\author{
Elena R. Milaeva, ${ }^{1}$ Vladimir Yu. Tyurin, ${ }^{1}$ Yulia A. Gracheva, ${ }^{1}$ Margarita A. Dodochova, ${ }^{2}$ \\ Lydia M. Pustovalova, ${ }^{2}$ and Victor N. Chernyshev ${ }^{2}$ \\ ${ }^{1}$ Department of Organic Chemistry, M. V. Lomonosov Moscow State University, 119992 Moscow, Russia \\ ${ }^{2}$ Department of Biochemistry, Rostov State Medicinal University, 344022 Rostov on Don, Russia
}

Received 19 June 2006; Revised 15 August 2006; Accepted 10 October 2006

The in vivo effect of trimethyltin chloride $\left(\mathrm{Me}_{3} \mathrm{SnCl}\right)$, free base meso-tetrakis(3,5-di-tert-butyl-4-hydroxyphenyl)porphyrin $\left(\mathrm{R}_{4}^{\prime} \mathrm{PH}_{2}\right)$ and their equimolar mixture, on the enzymatic activity of catalase (CAT), superoxide dismutase (SOD), and on the total content of free sulfhydryl groups has been studied in rat liver and kidney. It was demonstrated that the simultaneous treatment of tested animals with the combination of $\mathrm{Me}_{3} \mathrm{SnCl}$ and $\mathrm{R}_{4}^{\prime} \mathrm{PH}_{2}$ reduced the toxic impact of $\mathrm{Me}_{3} \mathrm{SnCl}$.

Copyright ( 92006 Elena R. Milaeva et al. This is an open access article distributed under the Creative Commons Attribution License, which permits unrestricted use, distribution, and reproduction in any medium, provided the original work is properly cited.

\section{INTRODUCTION}

Organotin compounds find a considerably application in industry and agriculture and the subsequent discharge of toxic organotins into the environment is a topic of great concern $[1,2]$. Among the organotins $\mathrm{R}_{\mathrm{n}} \mathrm{SnX}_{4-\mathrm{n}}$ trimethyltin species $\mathrm{Me}_{\mathrm{n}} \mathrm{SnX}_{4-\mathrm{n}}$ are of particular importance since these compounds are formed in the environment in biomethylation processes [3].

The toxicity of organotins is associated with their ability to react with free $\mathrm{SH}$-groups in proteins and glutathione and to inhibit the activities of some enzymes.

On the other hand, it is well known that organotins induce oxidative stress in the living organism through multiple mechanisms including the enhancement of the intracellular generation of reactive oxygen species (ROS), $\mathrm{H}_{2} \mathrm{O}_{2}$, $\mathrm{O}_{2}^{-\bullet}, \mathrm{HO}^{\bullet}[4]$. The involvement of $\mathrm{R}_{\mathrm{n}} \mathrm{SnX}_{4-\mathrm{n}}$ in radical and redox biochemical processes is manifested in $\mathrm{C}-\mathrm{Sn}$ bond homolytic cleavage that leads to the generation of reactive Ccentered organic radicals $\mathrm{R}^{\bullet}[5]$. Thus a very reactive methyl radical $\mathrm{CH}_{3}^{-}$might be formed when methyl derivatives of tin, $\mathrm{Me}_{\mathrm{n}} \mathrm{SnX}_{4-\mathrm{n}}$, participate in biochemical radical reactions. The consequences of this impact are the perturbation of the antioxidative defense system and the promotion of a cascade of radical processes. On the other hand, the metal ions formed in the biodegradation of organotins are promoters of radical processes.
Therefore, an intriguing aspect of the behavior of organotins $\mathrm{R}_{\mathrm{n}} \mathrm{SnX}_{4-\mathrm{n}}$ is their ability to manifest the activity of metal containing prooxidants and chain radical reactions promoters as well.

The disruption of the oxidative status in the living organism can be prevented or inhibited by cellular antioxidants. Toxic doses of organotin compounds are capable of disturbing the natural oxidation/reduction balance in cells through various mechanisms originating from their own complex oxidative/radical reactions with endogenous oxidants. The consequences of these reactions produce some effects on cellular antioxidant systems, cellular membranes, and membrane-dependent redox sensitive enzymatic systems. This, in turn, may produce a variety of toxic effects, including pathological processes, which lead to the cells death.

Therefore, there is an urgent need to find new detoxification agents to prevent or inhibit the disruption of the cellular antioxidative system when organotins are involved.

Processes caused by active radical species are prevented or inhibited by treating the organism with natural or synthetic antioxidants. The application of chelating agents such as metal scavengers seems to be important in order to exclude the impact of the metal ion.

Lately, a new approach has been proposed [6] to prevent the prooxidative activity of organotins by applying a specific polytopic compound capable of acting as an antioxidant and 
a metal ion scavenger-free base meso-tetrakis(3,5-di-tertbutyl-4-hydroxyphenyl)porphyrin, $\mathrm{R}_{4}^{\prime} \mathrm{PH}_{2}$. This exogenous compound acts as an inhibitor since its molecules contain the antioxidative phenol moieties, analogues of vitamins $\mathrm{E}$ group. The other pathway of $\mathrm{R}_{4}^{\prime} \mathrm{PH}_{2}$ is associated with the ability of free base porphyrins to incorporate metal ions in their core and to form stable metal complexes.

The influence of $\mathrm{Me}_{2} \mathrm{SnCl}_{2}, \mathrm{Et}_{2} \mathrm{SnCl}_{2}$, and $\mathrm{SnCl}_{2}$ upon the radical chain oxidation of Z-9-octadecenoic (oleic) acid as model substrate for lipid peroxidation in the simultaneous presence of $\mathrm{R}_{4}^{\prime} \mathrm{PH}_{2}$ has been studied [6]. The free base porphyrin $\mathrm{R}_{4}^{\prime} \mathrm{PH}_{2}$, containing the antioxidative phenol moieties (2,6-di-tert-butylphenol), demonstrates an acute inhibitory effect upon the oleic acid's peroxidation in the presence of organotins.

Thus we suppose that meso-tetrakis(3,5-di-tert-butyl-4hydroxyphenyl)porphyrin can act as an antioxidant and a scavenger for metal and can be used as a new antioxidative scavenger preventing the toxic impact of organotin compounds.

The goal of the present study is to evaluate the in vivo protective effect of meso-tetrakis(3,5-di-tert-butyl-4-hydroxyphenyl)porphyrin against the impact of $\mathrm{Me}_{3} \mathrm{SnCl}$ upon the components of antioxidative defense system (catalase and superoxide dismutase) using rats as tested organisms. The total level of $\mathrm{SH}$-groups as a marker of $\mathrm{Me}_{3} \mathrm{SnCl}$ impact upon proteins containing thiol groups and glutathione in rats' organs has been studied as well.

\section{EXPERIMENTAL}

\section{Materials and instruments}

The following materials were obtained commercially and used as supplied: $\mathrm{Me}_{3} \mathrm{SnCl}$ (Strem), $\left(\mathrm{NH}_{4}\right)_{6} \mathrm{MO}_{7} \mathrm{O}_{24}, 5,5^{\prime}$ dithio-bis(2-nitrobenzoic) acid (DTNB), nitroblue tetrazolium (NBT), EDTA (Sigma). Free base meso-tetrakis(3,5di-tert-butyl-4-hydroxyphenyl)porphyrin was synthesized as previously described by the known procedure [7], purified by silica gel column chromatography using $\mathrm{CHCl}_{3}, 80 \% \mathrm{CHCl}_{3}$ and $20 \%$ hexane as the eluting solvents, and identified by UV-vis and IR spectroscopy. Deionized water purified with Simplicity Proto system (Millipore) was used. The solutions of $\mathrm{Me}_{3} \mathrm{SnCl}$ were prepared by dissolving the precise quantity of the compound in Tween-80. The solutions of $\mathrm{Me}_{3} \mathrm{SnCl}$ were prepared directly before the analysis. Spectrophotometric study was performed by using spectrophotometer SF-46 (LOMO, Russia) and Varian 100S spectrophotometer. Infrared (IR) spectra were recorded on a Perkin Elmer "Spectrum One" spectrophotometer.

\section{Experimental animals}

Adult female Wistar rats (200-220 g body wt) were used throughout experiments. The animals were divided into 4 groups (a control group of animals that did not receive any treatment, three experimental groups of animals which received either $\mathrm{Me}_{3} \mathrm{SnCl}$ or meso-tetrakis(3,5-di-tert-butyl-4hydroxyphenyl)porphyrin or their combination, resp; each group contained 5 animals). The animals were given a single oral additive's dose of $5 \mathrm{mg} \cdot \mathrm{kg}$ body wt. This is a less amount of $\mathrm{Me}_{3} \mathrm{SnCl}$ than the oral $\mathrm{LD}_{50}$-dose of about $9 \mathrm{mg} \cdot \mathrm{kg}$ [8]. The simultaneous oral treatment of the animals with $\mathrm{Me}_{3} \mathrm{SnCl}$ and meso-tetrakis(3,5-di-tert-butyl-4hydroxyphenyl)porphyrin was performed in an analogous way by using the same doses. The rats were clearly affected by the treatment (diminished mobility, anxiety, aggression). However, none of the tested animals died during the experiment. The animals were killed after $24 \mathrm{~h}$, the livers and kidneys were immediately removed, rinsed with ice-cold saline, homogenized in $0.05 \mathrm{M}$ phosphate buffer ( $\mathrm{pH} 7.4$ ) and $0.1 \mathrm{mM}$ EDTA using a motor-driven Teflon-glass homogenizer followed by ultrasonification as described previously [9]. After centrifugation at $2000 \times \mathrm{g}$ for $10 \mathrm{~min}$, the supernatant was used for the analysis.

\section{Measurement of catalase and superoxide dismutase activities and the content of glutathione}

The liver and kidney tissues were used for measurement of catalase (CAT) (EC 1.11.1.6) and superoxide dismutase (SOD) (EC 1.15.1.1) activities as well as for measuring the content of free sulfhydryl groups.

The assay for the determination of catalase activity was carried out as described previously $[10,11]$ by a method based on the disappearance of $\mathrm{H}_{2} \mathrm{O}_{2}$ in the reaction of hydrogen peroxide with $\left(\mathrm{NH}_{4}\right)_{6} \mathrm{MO}_{7} \mathrm{O}_{24}$ monitored spectrophotometrically at $410 \mathrm{~nm}$.

The assay for the determination of SOD activity was carried out as described previously [12] by a method using nitroblue tetrazolium (NBT) as the indicator reagent spectrophotometrically at $560 \mathrm{~nm}$ [11].

The content of $\mathrm{SH}$-groups was measured by the reaction of free sulfhydryl groups with 5,5'-dithio-bis(2nitrobenzoic) acid (DTNB) spectrophotometrically at $412 \mathrm{~nm}$ as described previously [13]. In all the experiments, Tween-80 impact upon the activity of CAT, SOD, and the content of SH-groups has been preliminary studied. No significant changes in the activities of enzymes and of the content of SH-groups have been observed.

\section{Statistical analysis}

All the data displayed in Table 1 and Figures 1, 2, and 3 are presented as means of several experiments \pm standard errors (SE) and represent treatment-induced changes. The assays of enzymes activities and free sulfhydryl groups' content were carried out in 8 or 12 parallel experiments. The significance of differences between experimental conditions was tested at the 5\% level $(P<.05)$. The Kolmogorov-Smirnov test was used to assess the normality of the distribution of each treatment [14].

\section{RESULTS AND DISCUSSION}

Organic derivatives of tin $\left(\mathrm{R}_{n} \mathrm{Sn} \mathrm{X}_{\mathrm{m}}\right)$ are supposed to induce oxidative stress in the living organism through multiple 
TABLE 1: Activities of catalase, superoxide dismutase, and total content of SH-groups in rat liver and kidney.*

\begin{tabular}{|c|c|c|c|c|c|c|}
\hline & \multicolumn{4}{|c|}{ Enzyme activity, $\mathrm{mmol} \cdot \mathrm{mg}^{-1} \cdot \mathrm{min}^{-1}$} & \multirow{2}{*}{\multicolumn{2}{|c|}{ Total content of SH-groups, $\mathrm{mmol} \cdot \mathrm{mg}^{-1}$}} \\
\hline & \multicolumn{2}{|c|}{ CAT } & \multicolumn{2}{|c|}{ SOD } & & \\
\hline & Liver & Kidney & Liver & Kidney & Liver & Kidney \\
\hline Control & $241.0 \pm 11.0$ & $157.6 \pm 5.8$ & $12.8 \pm 0.5$ & $6.7 \pm 0.2$ & $155.4 \pm 6.4$ & $136.3 \pm 6.5$ \\
\hline $\mathrm{Me}_{3} \mathrm{SnCl}$ & $136.5 \pm 6.7$ & $102.1 \pm 3.8$ & $1.0 \pm 0.05$ & $0.5 \pm 0.01$ & $9.5 \pm 0.5$ & $32.8 \pm 0.8$ \\
\hline $\mathrm{Me}_{3} \mathrm{SnCl}+\mathrm{R}_{4}^{\prime} \mathrm{PH}_{2}$ & $164.8 \pm 6.4$ & $128.2 \pm 1.9$ & $3.8 \pm 0.06$ & $2.1 \pm 0.1$ & $99.4 \pm 3.8$ & $62.6 \pm 3.2$ \\
\hline $\mathrm{R}_{4}^{\prime} \mathrm{PH}_{2}$ & $224.8 \pm 8.4$ & $144.9 \pm 4.3$ & $10.8 \pm 0.4$ & $6.6 \pm 0.3$ & $139.1 \pm 6.9$ & $132.1 \pm 0.5$ \\
\hline
\end{tabular}

* After $24 \mathrm{~h}$ of oral treatment of rats with both trimethyltin chloride and porphyrin $\mathrm{R}_{4}^{\prime} \mathrm{PH}_{2}$ each alone as well as in combination $(P<.05$ versus control). Data \pm SE $(n=8-12) ; n=$ number of replicates of enzyme activity measurements.
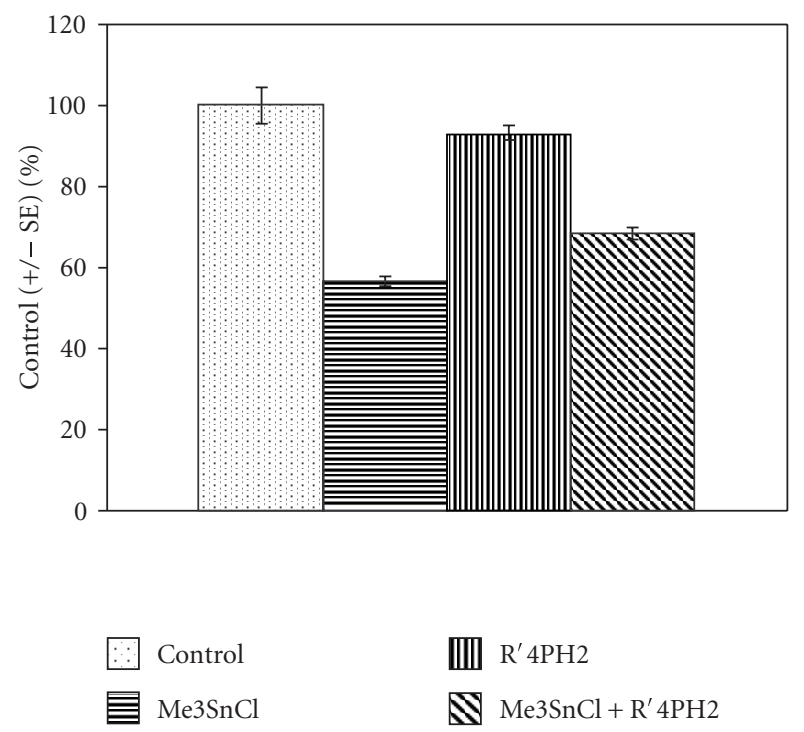

Figure 1: Effect of $\mathrm{Me}_{3} \mathrm{SnCl}, \mathrm{R}_{4}^{\prime} \mathrm{PH}_{2}$, and their combination exposure on the activity of CAT in rat liver (rat liver was isolated after $24 \mathrm{~h}$ after the animals were pretreated orally with $5 \mathrm{mg} \cdot \mathrm{kg}^{-1} \mathrm{wt}$ of $\mathrm{Me}_{3} \mathrm{SnCl}, \mathrm{R}_{4}^{\prime} \mathrm{PH}_{2}$, and their combination, resp; $\left.P<.05\right)$.

mechanisms including the intracellular generation of reactive oxygen species (ROS) [1, 3, 4, 15-17], depletion of $\mathrm{SH}$-groups in proteins and glutathione, promotion of lipid peroxidation, and perturbation of antioxidant defense system [4]. To understand the biomolecular mode of organotin compounds action, the participation of various $\mathrm{R}_{n} \mathrm{SnX}_{\mathrm{m}}$ in key biochemical processes responsible for the damage of the antioxidative defense system should be further studied.

The involvement of $\mathrm{R}_{\mathrm{n}} \mathrm{SnX}_{\mathrm{m}}$ in oxidative/free radical reactions may include the reactions of these compounds with very reactive radical species. These processes lead to the homolytic cleavage of $\mathrm{C}-\mathrm{Sn}$ bond and result in the formation of reactive organic radicals $\mathrm{R}^{\bullet}$ responsible for the enhanced perturbation of the antioxidative defense system and cell death [5]. Therefore, there is a need to elaborate a new approach in order to prevent or inhibit the impact of $\mathrm{R}_{n} \mathrm{SnX}_{4-\mathrm{n}}$ upon the complex antioxidative defense system.

Methyl derivative of $\mathrm{Sn}(\mathrm{IV})$ possessing three methyl groups $\left(\mathrm{Me}_{3} \mathrm{SnCl}\right)$ was selected for the investigation since there was strong evidence that this compound is the dominant species presented in biota $[1,3]$.
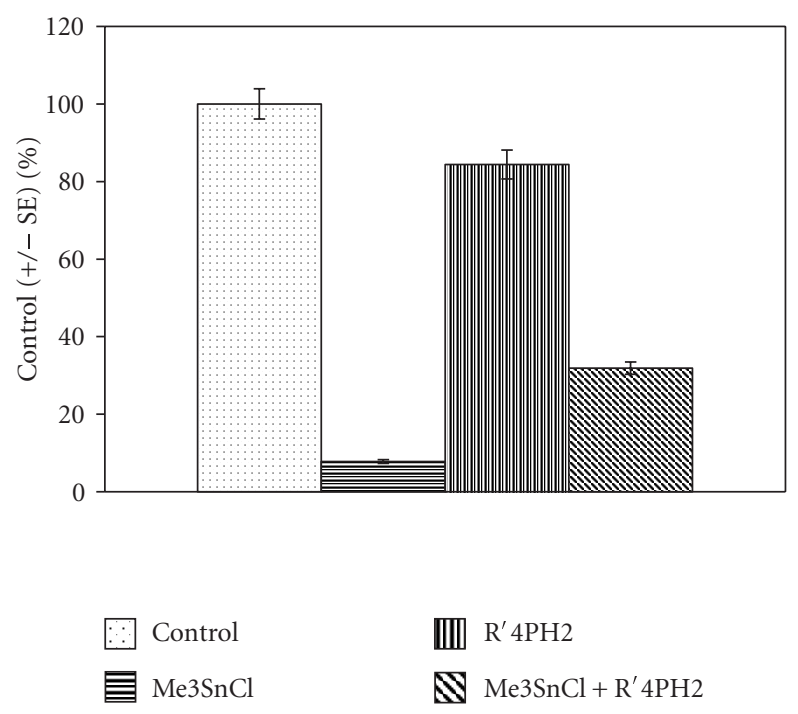

Figure 2: Effect of $\mathrm{Me}_{3} \mathrm{SnCl}, \mathrm{R}_{4}^{\prime} \mathrm{PH}_{2}$, and their combination exposure on the activity of SOD in rat liver (rat liver was isolated after $24 \mathrm{~h}$ after the animals were pretreated orally with $5 \mathrm{mg} \cdot \mathrm{kg}^{-1}$ wt of $\mathrm{Me}_{3} \mathrm{SnCl}, \mathrm{R}_{4}^{\prime} \mathrm{PH}_{2}$, and their combination, resp; $\left.P<.05\right)$.

A new efficient route to prevent the prooxidative activity of the organotin compounds was proposed and based on free base porphyrin containing antioxidative phenolic groups (meso-tetrakis(3,5-di-tert-butyl-4-hydroxyphenyl)porphyrin) [6] (see Scheme 1).

It was established that this compound acts as an effective antioxidant inhibiting the peroxidation of oleic acid in the presence of organotins [18]. Moreover, free base porphyrins are capable of incorporating metal ions in their core [19] when these macrocyclic compounds are involved in oxidative/radical processes.

\section{Effect of trimethyltin chloride and meso-tetrakis(3,5-di- tert-butyl-4-hydroxyphenyl)porphyrin upon the activity of catalase}

Both organic and inorganic tins have been found to decrease the activity of catalase- an $\mathrm{H}_{2} \mathrm{O}_{2}$ scavenger [20,21]. The mechanism of the enzyme inhibition is associated with the interaction of $\mathrm{Sn}$ center with free $\mathrm{SH}$-groups in protein. Trimethyltin chloride is capable of interacting with 

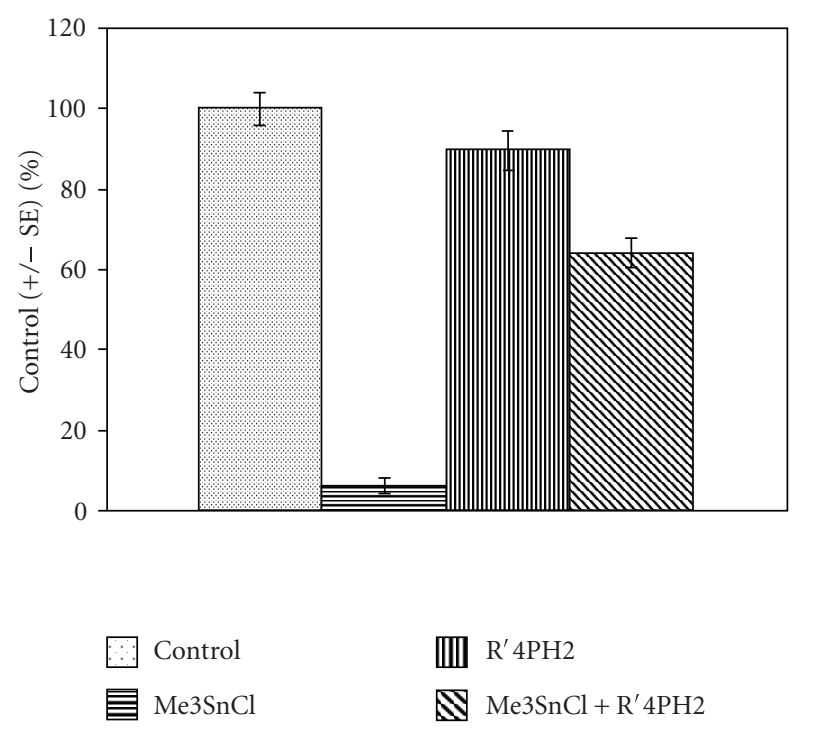

Figure 3: Effect of $\mathrm{Me}_{3} \mathrm{SnCl}, \mathrm{R}_{4}^{\prime} \mathrm{PH}_{2}$, and their combination exposure on $\mathrm{SH}$-groups content in rat liver (rat liver was isolated after $24 \mathrm{~h}$ after the animals were pretreated orally with $5 \mathrm{mg} \cdot \mathrm{kg}^{-1}$ wt of $\mathrm{Me}_{3} \mathrm{SnCl}, \mathrm{R}_{4}^{\prime} \mathrm{PH}_{2}$, and their combination, resp; $P<.05$ ).

SH-groups according to the nucleophilic substitution reaction of chlorine atom at metal center. On the other hand, the inorganic tin formed in the dealkylation of $\mathrm{Me}_{3} \mathrm{SnCl}$ in radical substitution reactions may also interact readily with $\mathrm{SH}$-groups. Therefore the protective effect of $\mathrm{R}_{4}^{\prime} \mathrm{PH}_{2}$ might be of importance since both centers in its molecule are responsible for both radical processes inhibition and metal ion scavenging.

The influence of these substances upon the enzyme activity in rat liver and kidney was studied. The data for enzymes activity and free sulfhydryl groups content are presented in Table 1 and given in Figure 1 as percent of control $( \pm$ SE).

It was shown that the catalytic activity of CAT significantly decreased when the animals were treated orally with the dose of $\mathrm{Me}_{3} \mathrm{SnCl} 5 \mathrm{mg} \cdot \mathrm{kg}^{-1} \mathrm{wt}$. At the same time it was observed that the same amount of $\mathrm{R}_{4}^{\prime} \mathrm{PH}_{2}$ had almost no effect on CAT activity, whereas $\mathrm{Me}_{3} \mathrm{SnCl}$ at the same concentration inhibited the enzyme sufficiently. The treatment of the tested animals with the combination of both additives is manifested in the significant decrease in $\mathrm{Me}_{3} \mathrm{SnCl}$ impact upon the enzyme.

\section{Effect of trimethyltin chloride and meso-tetrakis(3,5-di- tert-butyl-4-hydroxyphenyl)porphyrin upon the activity of superoxide dismutase}

Superoxide dismutase (SOD) is involved in the functioning of cellular antioxidative system and is responsible for the dismutation of highly toxic superoxide radical anion $\mathrm{O}^{\bullet-}$ in cells. The inhibition of this antioxidant enzyme activity by metals is a well-known fact [22]. The inhibition of SOD is discussed as one of the mechanisms of organotins cytotoxicity as well $[2,4,5]$.

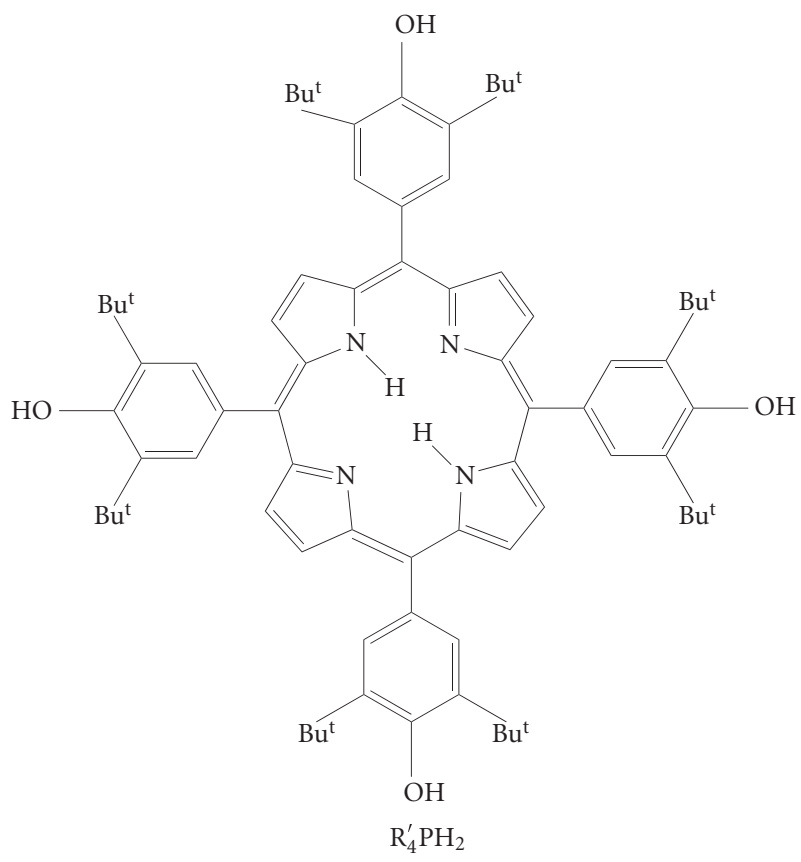

Scheme 1

The data are presented in Table 1 and Figure 2 for both isolated liver and kidney tissues when rats were treated with the dose of $\mathrm{Me}_{3} \mathrm{SnCl} 5 \mathrm{mg} \cdot \mathrm{kg}^{-1}$ wt. The results are analogous to the previous ones presenting the effect of additives on the CAT activity. The equal dose of $\mathrm{R}_{4}^{\prime} \mathrm{PH}_{2}$ does not show any significant effect on SOD activity, whereas the treatment of rats with the mixture of both compounds is manifested in significant modulation of $\mathrm{Me}_{3} \mathrm{SnCl}$ impact upon the enzymatic activity.

\section{Effect of trimethyltin chloride and meso-tetrakis(3,5-di- tert-butyl-4-hydroxyphenyl)porphyrin upon the content of free sulfhydryl groups}

In the present study the content of free $\mathrm{SH}$-groups has been examined as a biomarker of the protective effect of $\mathrm{R}_{4}^{\prime} \mathrm{PH}_{2}$ against the toxic impact of $\mathrm{Me}_{3} \mathrm{SnCl}$. The results are given in Table 1 and Figure 3. The protective effect of porphyrin $\mathrm{R}_{4}^{\prime} \mathrm{PH}_{2}$ for both experimental tissues-liver and kidneyisolated after the treatment of rats is very significant. These experimental results suggest that the interaction of $\mathrm{Me}_{3} \mathrm{SnCl}$ (or of inorganic tin as the product of $\mathrm{Me}_{3} \mathrm{SnCl}$ decomposition) may be prevented by the application of $\mathrm{R}_{4}^{\prime} \mathrm{PH}_{2}$.

Thus, it was demonstrated that trimethyltin chloride causes the inhibition of CAT and SOD catalytic activities that can be explained in terms of possible coupling with $\mathrm{SH}-$ groups of the enzymes. The decrease in the content of free sulfhydryl groups in rat tissues was observed as well.

Recently, we have studied the influence of methyltins $\left(\mathrm{MeSnCl}_{3}, \mathrm{Me}_{2} \mathrm{SnCl}_{2}\right.$, and $\left.\mathrm{Me}_{3} \mathrm{SnCl}\right)$, and inorganic tins $\left(\mathrm{SnCl}_{2}, \mathrm{SnCl}_{4}\right)$ on the enzymatic activities of NAD-dependent horse liver alcohol dehydrogenase $(\mathrm{ADH})$ in the reaction of ethanol oxidation [23] and NAD-dependent lactate 
dehydrogenase isolated from fish liver [24]. The results show that inorganic tins and organotins induce inhibition of the catalytic activity of horse liver alcohol dehydrogenase. It also turned out that the mechanism of methyltins action is more complex than the proposed interaction of Sn with $\mathrm{SH}$-groups of the enzyme protein. It was clearly demonstrated that the tin compounds act as oxidative agents towards coenzyme $\mathrm{NADH}$ as well.

Therefore, the results allow one to suggest that both mechanisms (coupling with the $\mathrm{SH}$-groups in proteins and involvement in oxidative/radical processes) might be responsible for the impact of $\mathrm{Me}_{3} \mathrm{SnCl}$ upon the cellular antioxidative enzymatic system. The decrease of $\mathrm{Me}_{3} \mathrm{SnCl}$ effect in the simultaneous presence of $\mathrm{R}_{4}^{\prime} \mathrm{PH}_{2}$ confirms the assumption that this polytopic compound might act as a radical and metal scavenger.

\section{CONCLUSION}

In summary, the presented experimental results of this in vivo study show that trimethyltin chloride induces the inhibition of the catalytic activities of CAT and SOD in rat liver and kidney and decreases the level of free $\mathrm{SH}$-groups as well. It was demonstrated that the simultaneous treatment of tested rats with free base meso-tetrakis(3,5-di-tert-butyl-4hydroxyphenyl)porphyrin significantly attenuates $\mathrm{Me}_{3} \mathrm{SnCl}$ toxic impact. Taken together, our results suggest that porphyrin containing antioxidative phenol fragments might act as a radical and metal scavenger.

\section{ACKNOWLEDGMENTS}

This work was supported by the Russian Foundation for $\mathrm{Ba}$ sic Research (Grants no. 05-03-32864, 06-03-32773, 06-0332731) and by the Program "Biomolecular and Medicinal Chemistry" of Russian Academy of Sciences.

\section{REFERENCES}

[1] Crompton TR. Occurrence and Analysis of Organometallic Compounds in the Environment. New York, NY: John Wiley \& Sons; 1998.

[2] Gadd GM. Microbial interactions with tributyltin compounds: detoxification, accumulation, and environmental fate. The Science of the Total Environment. 2000;258(1-2):119127.

[3] Craig PJ, Glockling F, eds. The Biological Alkylation of Heavy Elements. London, UK: Royal Society of Chemistry; 1988.

[4] Sergent O, Morel I, Cillard J. Involvement of metal ions in lipid peroxidation: biological implications. In: Sigel A, Sigel H, eds. Metal Ions in Biological Systems. Vol 36. New York, NY: Marcel Dekker; 1999:251.

[5] Milaeva ER, Petrosyan V, Berberova N, Pimenov Y, Pellerito L. Organic derivatives of mercury and tin as promoters of membrane lipid peroxidation. Bioinorganic Chemistry and Applications. 2004;2(1-2):69-91.

[6] Milaeva ER, Tyurin VYu, Shpakovsky D, Gerasimova O, Jingwei Z, Gracheva YA. Organotins-promoted peroxidation of unsaturated fatty acids: a new antioxidative scavenger for promoters. Heteroatom Chemistry. 2006;17(6):475-480.
[7] Milgrom LR. The facile aerial oxidation of a porphyrin. Tetrahedron. 1983;39(23):3895-3898.

[8] Reuhl KR, Cranmer JM. Developmental neuropathology of organotin compounds. Neurotoxicology. 1984;5(2):187-204.

[9] Steckelbroeck S, Stoffel-Wagner B, Reichelt R, Schramm J, Bidlingmaier F, Siekmann L. Characterization of $17 \beta$ hydroxysteroid dehydrogenase activity in brain tissue: testosterone formation in the human temporal lobe. Journal of $\mathrm{Neu}$ roendocrinology. 1999;11(6):457-464.

[10] Korolyuk MA, Ivanova LI, Mayorova IG, Tokarev VE. Method for catalase activity determination [in Russian]. Laboratornoe Delo. 1988;1:16-18.

[11] Pedraza-Chaverri J, Granados-Silvestre MA, Medina-Campos ON, Maldonado PD, Olivares-Corichi IM, Ibarra-Rubio ME. Post-transcriptional control of catalase expression in garlictreated rats. Molecular and Cellular Biochemistry. 2001;216(12):9-19.

[12] Fridovich I. Superoxide radical and superoxide dismutases. Annual Review of Biochemistry. 1994;64:97-112.

[13] Ji LL, Fu R. Responses of glutathione system and antioxidant enzymes to exhaustive exercise and hydroperoxide. Journal of Applied Physiology. 1992;72(2):549-554.

[14] Zar JH. Biostatistical Analysis. Englewood Cliffs, NJ: PrenticeHall; 1984.

[15] Gennari A, Viviani B, Galli CL, Marinovich M, Pieters R, Corsini E. Organotins induce apoptosis by disturbance of $\left[\mathrm{Ca}^{2+}\right]_{\mathrm{i}}$ and mitochondrial activity, causing oxidative stress and activation of caspases in rat thymocytes. Toxicology and Applied Pharmacology. 2000;169(2):185-190.

[16] Regolia F, Gorbia S, Frenzillib G, et al. Oxidative stress in ecotoxicology: from the analysis of individual antioxidants to a more integrated approach. Marine Environmental Research. 2002;54(3-5):419-423.

[17] Hamilton RJ, Kalu C, Prisk E, Padley FB, Pierce H. Chemistry of free radicals in lipids. Food Chemistry. 1997;60(2):193-199.

[18] Milaeva ER, Gracheva YA, Shpakovsky DB, Gerasimova OA, Tyurin VYu, Petrosyan VS. Oleic acid peroxidation in the presence of metallo-porphyrins. Journal of Porphyrins and Phthalocyanines. 2003;7(11):719-724.

[19] James BR. Interaction of dioxygen with metalloporphyrins. In: Dolphin D, ed. The Porphyrins. Vol 5. New York, NY: Academic Press; 1978:205-302.

[20] Barreraa D, Maldonadoa PD, Medina-Camposa ON, Hernández-Pandob R, Ibarra-Rubioa ME, Pedraza-Chaverrí J. Protective effect of $\mathrm{SnCl}_{2}$ on $\mathrm{K}_{2} \mathrm{Cr}_{2} \mathrm{O}_{7}$-induced nephrotoxicity in rats: the indispensability of HO-1 preinduction and lack of association with some antioxidant enzymes. Life Sciences. 2003;73(23):3027-3041.

[21] Geloso MC, Corvino V, Cavallo V, et al. Expression of astrocytic nestin in the rat hippocampus during trimethyltininduced neurodegeneration. Neuroscience Letters. 2004; 357(2):103-106.

[22] Fridovich I. Superoxide dismutases. Annual Review of Biochemistry. 1975;44:147-159.

[23] Bychkov PV, Shekhovtsova TN, Milaeva ER. Inhibition of horse liver alcohol dehydrogenase by methyltin compounds. Bioinorganic Chemistry and Applications. 2005;3(3-4):191199.

[24] Kolyada MN, Pimenov YT, Berberova NT, Milaeva ER, Kharitonashvili EV, Petrosyan VS. Effect of methyltin trichloride on the activity of lactate dehydrogenase. Russian Chemical Bulletin. 2001;50(8):1485-1488. 


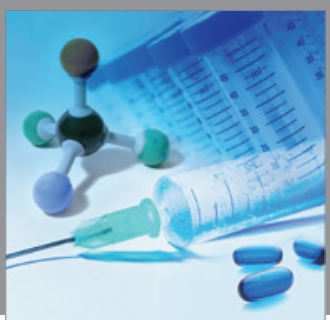

International Journal of

Medicinal Chemistry

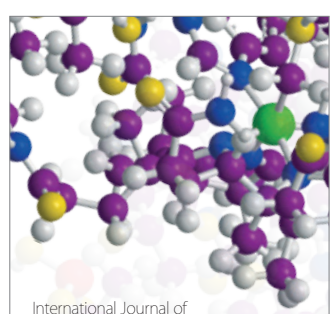

Carbohydrate Chemistry

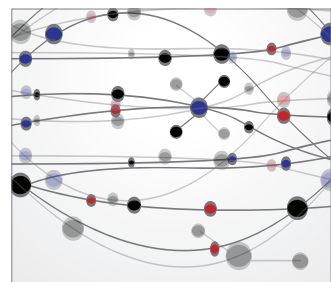

The Scientific World Journal
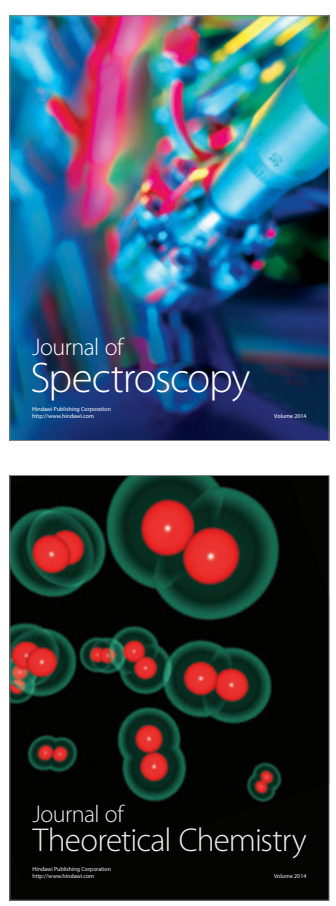
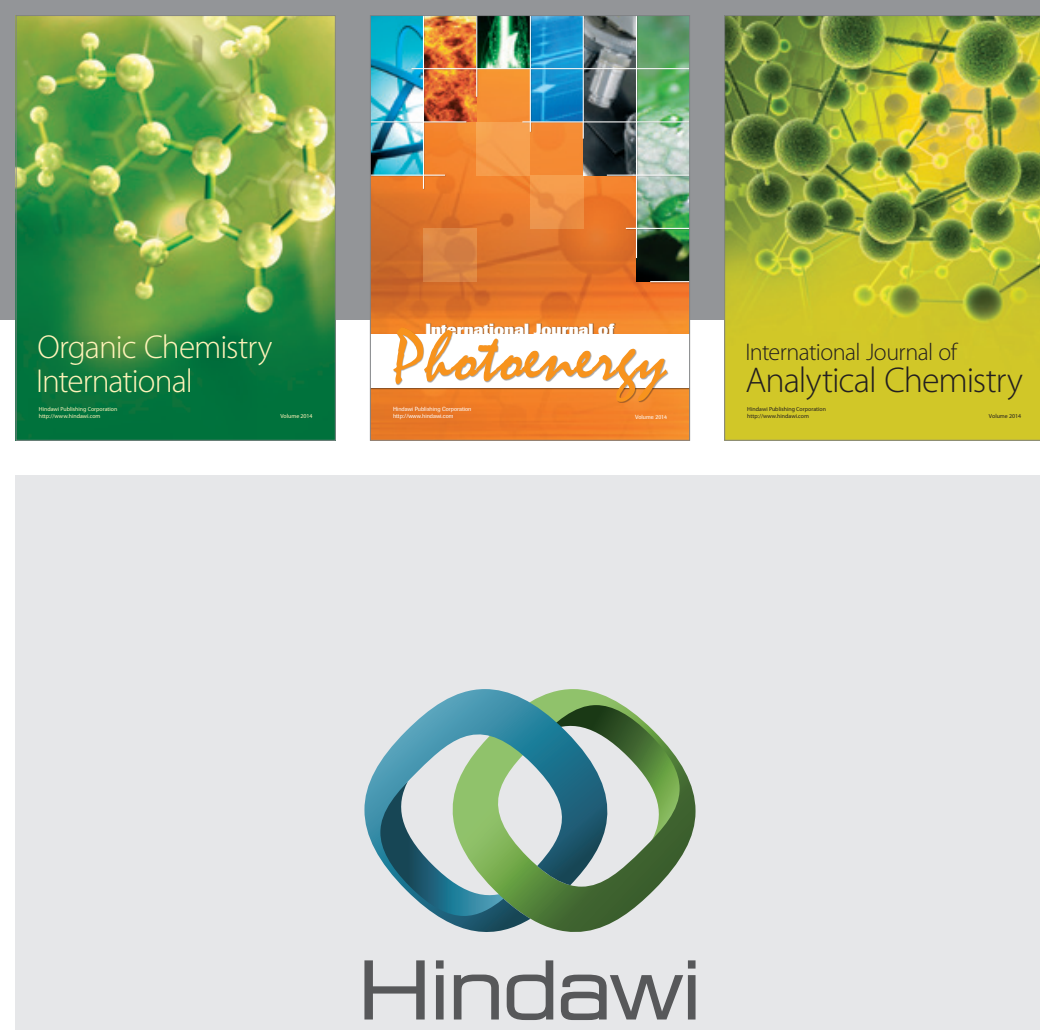

Submit your manuscripts at

http://www.hindawi.com
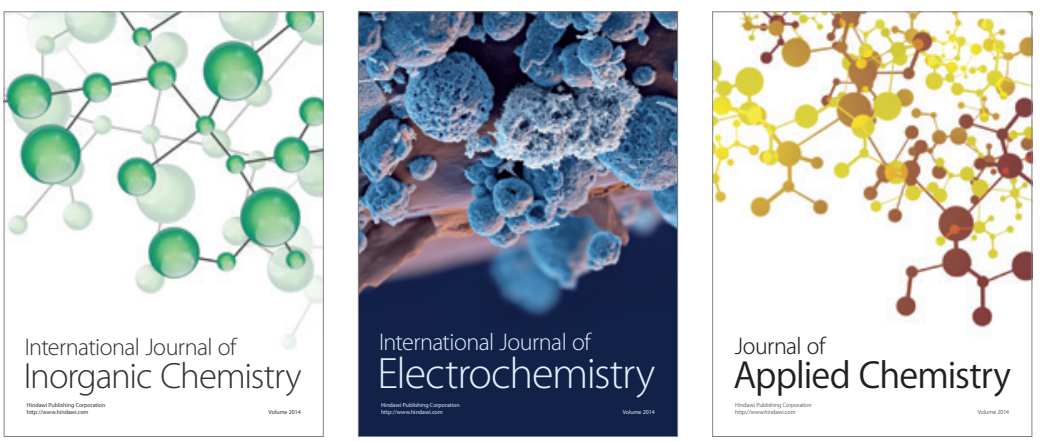

Journal of

Applied Chemistry
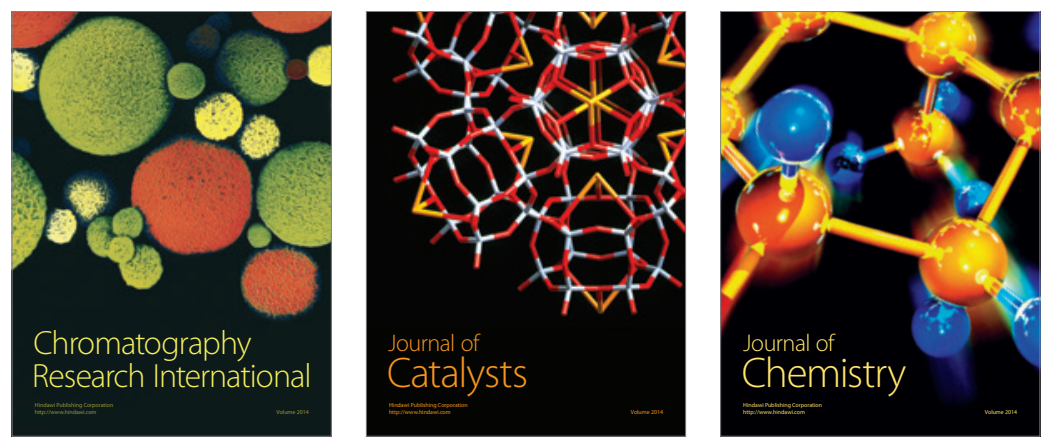
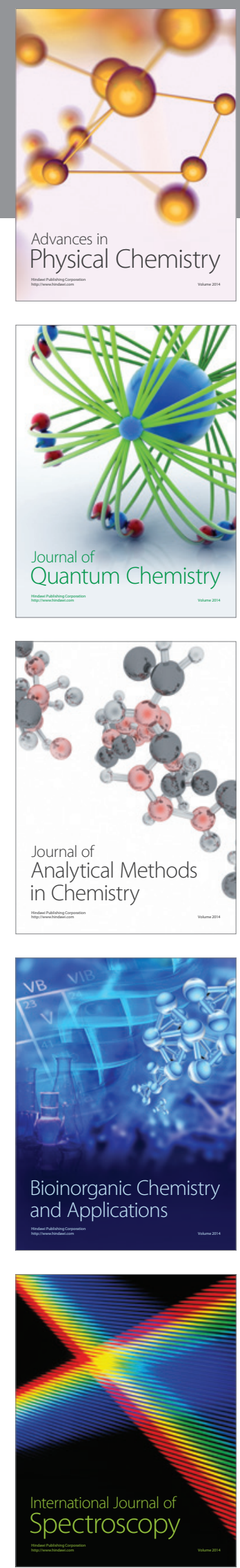